\title{
The empowerment strategy of Dangke microscale business management in Enrekang Regency, South Sulawesi, Indonesia
}

\section{La estrategia de empoderamiento de la gestión empresarial a microescala de Dangke en Enrekang Regency, South Sulawesi, Indonesia}

\author{
SOSE, Andi Tenry ${ }^{1}$ \\ MUSA, Chalid Imran ${ }^{2}$ \\ BADO, Basri ${ }^{3}$ \\ AZIZ, Muh ${ }^{4}$ \\ SAMAD, Sulaiman ${ }^{5}$
}

\begin{abstract}
:
An empowerment strategy is a way to organize manpower, funds, power and equipments in helping individuals, groups and communities to grow. This study used a qualitative method in which the informants were 10 Dangke business actors in Cendana District, Enrekang Regency. The results showed that the strategy of empowering the Dangke micro-scale business manager contributes in improving the management of Dangke micro-scale business. It can be seen from the aspects of marketing volume, labor, increased income, and the breadth of the market.

Keywords: empowerment, strategy, production, marketing.

Resumen

Una estrategia de empoderamiento es una forma de organizar la mano de obra, los fondos, el poder y los equipos para ayudar a crecer a las personas, los grupos y las comunidades. Este estudio utilizó un método cualitativo en el que los informantes fueron 10 actores de negocios Dangke en el distrito de Cendana, Enrekang. Los resultados mostraron que la estrategia de empoderar al gerente de micro escala de Dangke contribuye a mejorar la gestión de las microempresas de Dangke. Se puede ver en los aspectos del volumen de marketing, la mano de obra, el aumento de los ingresos y la amplitud del mercado.

Palabras clave: empoderamiento, estrategia, producción, el márketing.
\end{abstract}

\section{Introduction}

Enrekang Regency which is located in South Sulawesi, Indonesian, is rich in natural resources and very fertile. The majorit of its population makes a living in the agricultural sector of approximately $75 \%$ (Tribun Enrekang,

\footnotetext{
${ }^{1}$ Department of Economic, Universitas Negeri Makassar, South Sulawesi, Indonesia. e-mail: anditenrysose@gmail.com

${ }^{2}$ Professor, Universitas Negeri Makassar, Affiliate Professor Universitas Negeri Makassar, South Sulawesi, Indonesia. e-mail: imranmusa1962@gmail.com ${ }^{3}$ Docente de Tiempo Completo, Universitas Negeri Makassar, South Sulawesi, Indonesia. e-mail: basri.bado@unm.ac.id

${ }^{4}$ Professor, Universitas Negeri Makassar, Affiliate Professor Universitas Negeri Makassar, South Sulawesi, Indonesia. e-mail: azis_feunm@yahoo.com.

${ }^{5}$ Docente de Tiempo Completo, Universitas Negeri Makassar, South Sulawesi, Indonesia. e-mail: sulaimansamad@unm.ac.id
} 
2019). The data from the Regional Study and Finance of the Province of South Sulawesi in 2018 stated that Enrekang District has been designated as a potential area in South Sulawesi to become an agro-tourism area. This is what makes the Enrekang Regency Government try to encourage other businesses besides agriculture.

Dangke is a traditional food that originally comes from Enrekang Regency, South Sulawesi, which the raw material comes from cow's milk. The Enrekang Regency Government has made Dangke as a superior and popular traditional food product. This product has great potential to become a source of the local income which is contains a high animal protein in order to meet the nutritional needs for the community.

Apart from being a popular traditional food in South Sulawesi, Dangke micro-scale business is a vehicle for increase the promotion of labor in rural areas that a driving force for the economy of the community. This kind of business gave the characteristics to all small businesses, and located in all corners of the country in order that that they are an effective distribution to reach most of the people (Panjung Rusnadi, 2009).

The performance of this family business can interpret changes in the external and internal business environment based on human resource competencies, organizational capabilities, knowledge management, and managerial experience (Henni Zainal et al., 2018).

This research is motivated by looking at the condition of the Dangke Micro Scale Business Managers in Enrekang Regency who have not been able to develop as a whole and to do production of Dangke. An empowerment strategy for micro-scale businesses receives special attention by the Government as stated in Law Number 20 of 2008, article 1 paragraph 8. This Law indicates that the empowerment of micro and small enterpreneurship needs to be carried out thoroughly, optimally and continuously in the widest possible development of businesses, so as to increase the potential of MSMEs in realizing economic growth, increasing people's income, creating jobs and alleviating poverty. Analyzed the effects of various strategies adopted by the management for employee empowerment (Kumar \& Kumar, 2017).

A research conducted by (Hapsary, 2008), indicates several obstacles faced by Dangke micro-scale business group in developing their business. The most basic problems were including: (1) Traditional Management Strategy, (2) Limited human resources quality. (3) Limited management capacity and use of Information Technology. The problems in the development of micro and small business including: lack of capital, difficulties in marketing, simple organizational structure with poor division of labor, low quality of management, limited and low quality of human resources, lack of financial reports, weak legal aspects, and low quality of technology(Situmorang \& Situmorang, 2008).

Another finding regarding the traditional food mass production shows that the main obstacle or classic problem is the low empowerment of micro business managers to improve marketing performance. The finding shows that the biggest obstacles faced by Dangke business are: (1) Product Marketing. (2) Low competitiveness. (3) Less Packaging. (4) High Production Costs. (5) long production time, and (6) lack of product innovation (Fajri llham, 2018).

This research focuses on the Empowerment Strategy in Entrepreneurship, Production, Marketing, and the Networking strategy.

\subsection{Theoretical Framework}

According to Robert Adams, in Social Work and Empowerment (2003), "the user participation in services and to self-help movement generally, in which groups take action on their own behalf, either in cooperation with, or independently of, the statutory service. Empowerment is used as a tool to help individuals, groups and communities in order that they are able to manage the environment and achieve their goals to work and help 
themselves and others to maximize their quality of life. Theory on Entrepreneurship Empowerment Strategy, says that basically the essence of entrepreneurship is to create something new and different (create new and different) through creative thinking and innovative action to create opportunities (Drucker, 2002).

The 2009 Carter Theory on Production Empowerment Strategy says that the amount of profit a company gets can be determined by the volume of production produced. The more production volume achieved, the higher the profit. This means that production costs affect profit. Theory of Marketing Empowerment Strategies says that Marketing management has two definitions, namely social and managerial. Socially, there is an exchange between the needs of two individuals and groups by offering and exchanging their products / services. Meanwhile, managerial marketing can be analogous to the art of selling products to consumers (Keller \& Lane, 2013).

The theory of Robbins and Timoty (2007) regarding Business Network Empowerment Strategies states that the organization as a system consisting of a pattern of collaborative activities carried out regularly and repeatedly by a group of people to achieve a goal. In achieving the objectives of the empowerment strategy, support between entrepreneurial partners is needed (Molefi, 2009).

\section{Methods}

This research uses a qualitative approach. As for the determination of key informants, 10 dangke business owners who manage their business for more than 5 years. The was collected through direct observation, interviews, documentation and Focus Group Discussion (FGD). The analysis used is a SWOT analysis by sorting which indicators include strengths, weaknesses, opportunities and threats. Then create a summary matrix of external factor analysis and internal factor analysis then identify the strategic position of the SWOT analysis results then describe the position of the strategy on the SWOT diagram.

\section{Results And Discussion}

The empowerment strategy of Dangke micro-scale businesses management carried out by the government in Enrekang Regency has not been successful as shown by poor development of Dangke business managers even though they have been running their business for a long time. There are also Dangke managers who have started to initiate the empowerment independently, even though it is not optimal. But there is one micro-scale business manager who has great attention to his business and makes breakthroughs in developing his business, doing selfdevelopment, making product innovations, and building business networks in the form of resellers in several cities. This manager has implemented 3 strategies durig his bisiness, including marketing, financial, and networking management. These strategies made the Dangke business that he run became successful.

The Dangke Micro Scale Business Manager has implemented an Entrepreneurship Empowerment Strategy by participating in trainings held in the form of empowerment assistance from the Government. The Production Empowerment Strategy has not been successful because there are still many Dangke business managers who lack of business capital. The employees training is part of the empowerment strategy but training is not carried out periodically due to limited budgets that cause training time to be limited. Budget availability and limited training time led to the optimal development of human resources strategy (Henni Zainal, Muhammad Rakib, Andi Idham Ashar, Darmawati Manda, Andi Tenry Sose, Ignasius Setitit, 2020). The Marketing Empowerment Strategy has also not been successful, because of the 10 informants studied, only 1 was able to own a shop with a sales window and was also able to have a reseller in several city districts. And the Business Network Empowerment strategy has also not been successful because all Dangke Business managers do not have an organizational structure and almost all do not have a partnership relationship. 
SWOT analysis through the identification of weights and ratings on the Internal Factor Analysis Summary (IFAS) matrix is a score of 4.8 as a result of the sum of weights / ratings of Strength and Weakness, while the External Factor Analysis Summary (EFAS) matrix scores 5.2 the results of the sum of weights / ratings of Opportunities and Threat.

Figure 1

In ternal Factor Analysis Summary (IFAS) Matrix

\begin{tabular}{|c|c|c|c|}
\hline Strength & Weight & Rating & Score \\
\hline 1 Affordable Product Prices. & 0,3 & 3 & 0,9 \\
\hline 2 Unique Qualitv and Taste. & 0,2 & 3 & 0,6 \\
\hline 3 Natural brocessine conceot. & 0,1 & 1 & 0,1 \\
\hline 4 Regional Characteristics. & 0,1 & 1 & 0,1 \\
\hline 5 High nutritionalvalue. & 0,3 & 2 & 0,6 \\
\hline Total & 1 & & 2,3 \\
\hline Weakness & Weight & Rating & Score \\
\hline 1 Raw Material Difficulty. & 0,3 & 3 & 0,9 \\
\hline 2 Capital Limitations. & 0,3 & 3 & 0,9 \\
\hline 3 Low Management. & 0,2 & 2 & 0,4 \\
\hline 4 Technology Limitations. & 0,1 & 1 & 0,1 \\
\hline 5 Lack of Promotion. & 0,1 & 2 & 0,2 \\
\hline Total & 1 & & 2,5 \\
\hline
\end{tabular}

In ternal Factor Analysis Summary (EFAS) Matrix

5,2

\begin{tabular}{|c|c|c|c|}
\hline Opportunity & Weight & Rating & Score \\
\hline 1 Main source of income of the family. & 0,3 & 3 & 0,9 \\
\hline 2 Economic growth in Enrekang Regency is improving. & 0,1 & 1 & 0,1 \\
\hline 3 Political \& Socialconducive. & 0,1 & 1 & 0,1 \\
\hline 4 Product demand is stable. & 0,3 & 3 & 0,9 \\
\hline 5 Typicalcharacteristics of Enrekang Regency. & 0,2 & 3 & 0,6 \\
\hline Total & 1 & & 2,6 \\
\hline Threat & Weight & Rating & Score \\
\hline 1 Natural disasters. & 0,4 & 2 & 0,8 \\
\hline 2 The level of business competition is getting higher. & 0,6 & 3 & 1,8 \\
\hline Total & 1 & & 2,6 \\
\hline
\end{tabular}

In the Cartesian diagram, the number of IFAS and EFAS is in quadrant I which shows support for the Aggressive Strategy (Growth Oriented Strategy). That is a very favorable situation for managers of micro-scale dangke businesses because they have strength and can take advantage of existing opportunities.

Figure 2

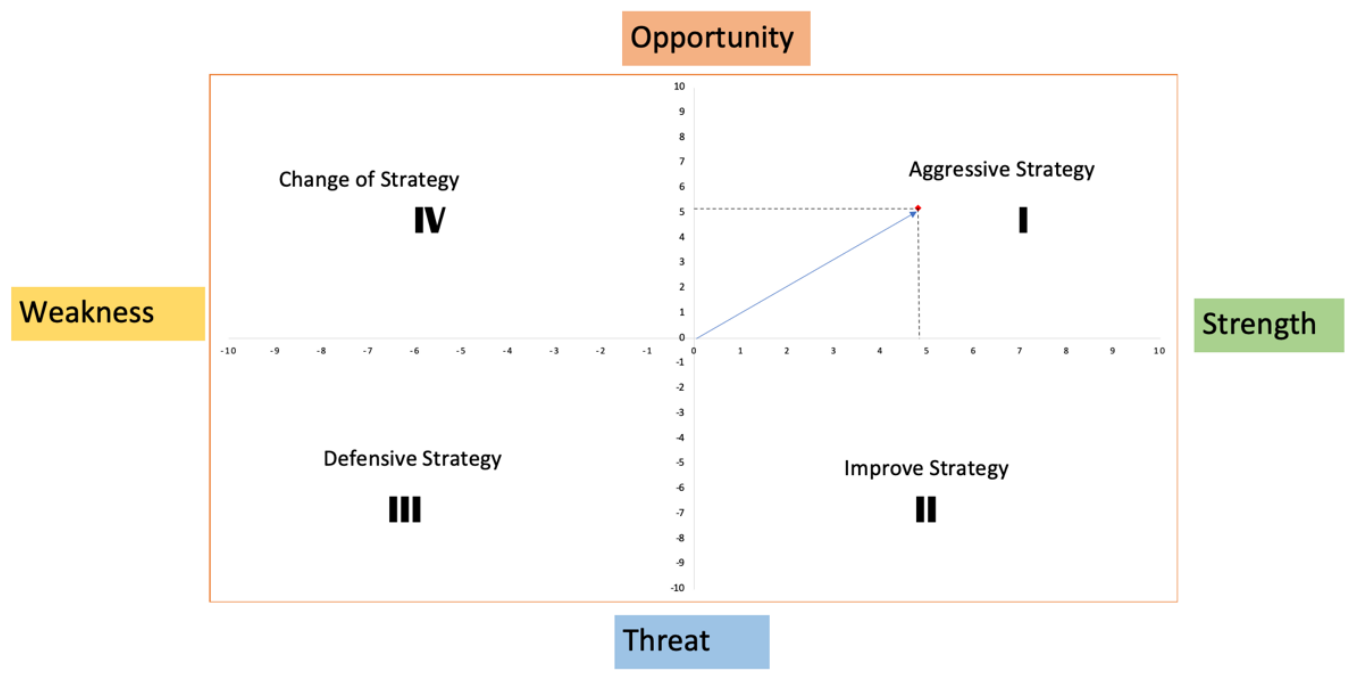

Then, successively carry out the SO, ST, WO, WT strategy. where SO is increasing the resources owned in order to increase production and develop various variants of Dangke processed products. ST is the use of materials and tools to be efficient and then increase promotional creativity. WO is improving product quality, adding marketing networks (resellers) and increasing business capital. Meanwhile, WT is to optimize capacity and make partnerships, as well as improve technology. 
Figure 3

\begin{tabular}{|l|l|l|}
\hline IFAS & \multicolumn{1}{|c|}{ STRENGTH (S) } & \multicolumn{1}{c|}{ WEAKNESS (W) } \\
\hline OPPORTUNITY (O) & $\begin{array}{l}\text { STRATEGY OPPORTUNITY (SO) : } \\
\text { Using Strength (Strength) to take } \\
\text { advantage of Opportunities } \\
\text { (Opportunities) that exist using } \\
\text { strength to take advantage of } \\
\text { opportunities }\end{array}$ & $\begin{array}{l}\text { STRATEGI WEAKNESS (WO) : } \\
\text { Continuously improving our } \\
\text { Weaknesses to take advantage } \\
\text { of Opportunity. Create a } \\
\text { strategy that minimizes } \\
\text { opportunities. }\end{array}$ \\
\hline THREATS (T) & $\begin{array}{l}\text { STRATEGY THREATS (ST) : } \\
\text { Create a strategy that uses } \\
\text { strength to overcome threats. }\end{array}$ & $\begin{array}{l}\text { STRATEGY THREATS (WT) : } \\
\text { Create a strategy that } \\
\text { Minimizes (Weaknesses) and } \\
\text { avoids (Threats), so that dangke } \\
\text { business can be maintained. }\end{array}$ \\
\hline
\end{tabular}

The description above shows that in addition to the Entrepreneurship Empowerment Strategy, Production Empowerment Strategy, Marketing Empowerment Strategy, and Business Network Empowerment Strategy, Dangke Business Managers still need one more Empowerment Strategy called the Aggressive Empowerment Strategy (attack / growth strategy: logical and conceptual thinking on matters. -Priority matters, both in the long term, short term and in urgent circumstances, so that the managers of the Dangke Micro Scale Business in Enrekang Regency can develop rapidly. Empowerment and development of MSMES is hampered by several factors, namely the market aspect, management aspects of financial aspects, and capital (Ali, Iskandar, 2019).

The implementation of Dangke micro-scale business management empowerment including entrepreneurship, production, marketing, and business network empowerment is still very poor. Therefore, Dangke business managers in Enrekang Regency need to be treated with marketing and production training to improve and develop their skill. This is supported by previous study conducted by Rakib \& Azis (2020) that entrepreneurship training, individual commitment, and business motivation have a direct and significant influence on the performance of small businesses. Increasing economic is critical in creating rational consumers, and can be achieved through formal economic education, non-formal educational training, or through informal education in the family (Azis et al., 2018).The implication of empowering micro-scale dangke business managers in this study is that these activities become beneficiaries or micro-scale Dangke business managers experience an increase in business income, although not all have increased.

The results of this study provide methodical implications for increasing business results in Dangke micro-scale management. Therefore, the government in implementing policies in determining directions and goals for the creation of institutions that can strengthen micro-scale business operators through cooperation with the government, universities, micro and community scale business operators whose function is to increase the empowerment of micro-scale businesses. This result is in line with the study conducted by (Harini \& Hambany, 2019) The development of the market network and marketing to improve competitiveness of empowerment in the field of production through the help of selective business sectors and stimulant. Productivity is one of the most important determinants of economic growth and the welfare of people (Kaasa, 2018). This study is supported by another study conducted by Kaplan and Norton (1996) model of empowering to give birth to a pioneer movement for micro-scale business management to small, medium and even large businesses. (Kaplan and Norton, 1996). SMEs are considered as the source of breeding ground for entrepreneurs in developing and developed countries (Ongori \& Migiro, 2011). 


\section{Conclusions}

The results showed that the empowerment of Dangke micro-scale business managers in Enrekang Regency, by giving cows as business capital and entrepreneurship training to educate the managers in doing business, was not sufficient to empower all Dangke business managers in Enrekang Regency. The results of the SWOT analysis are: 1) Entrepreneurship Empowerment, Production Empowerment, Marketing Empowerment, Business Network Empowerment and Aggressive Strategy is extremely needed by Dangke Micro-Scale Business Managers, efforts are made to help in the management process in order to encourage less productive resources to become productive, increase production volume and increase profits, increase skills in the aspect of selling products, social processes, and customer-oriented services, expand partnerships with organizational strengths, provide strength in finding and determining market opportunities.

\section{Bibliography}

Ali, Iskandar, H. D. (2019). MSMEs Empowerment and Development Strategy Model. 8(2), 324-332.

Azis, M., Makassar, U. N., Haeruddin, M. I. M., Makassar, U. N., Azis, F., \& Makassar, U. N. (2018). ENTREPRENEURSHIP EDUCATION AND CAREER INTENTION : THE PERKS OF BEING A WOMAN STUDENT. 21(1), 2651.

Drucker, P. F. (2002). Chapter 8: Management by Objectives and Self-Control". HarperBusiness Publishing.

Fajri Ilham. (2018). Strategies to Increase Sales of Traditional Sundanese Food through the Appeal of Culinary Tourism Products at The Jayakarta Bandung Suite Hotel \& Spa. Tourism and Hospitality Essentials (THE) Journal, 8(1).

Hapsary. (2008). Performance Improvement Planning, Suatu Pendekatan Perencanaan Peningkatan Kinerja (Prestasi Kerja). LAN.

Harini, S., \& Hambany, S. (2019).

Estrategia de empoderamiento de pequeñas y medianas empresas mediante la participación de las partes interesadas para aumentar el rendimiento. 04(02), 33-44. https://doi.org/10.33062/mjb.v4i2.334

Henni Zainal, Muhammad Rakib, Andi Idham Ashar, Darmawati Manda, Andi Tenry Sose, Ignasius Setitit. (2020). Strategy of human resources development in improving performance Apparatus in the Bone Regency Regional Inspectorate. Pinisi Business Administration Review, 2(1).

Henni Zainal, U. I. T., Parinsi, W. K., Indonesia, S. P., Hasan, M., \& Makassar, U. N. (2018). The Influence Of Strategic Assets And Market Orientation To The Performance Of Family Business In Makassar City, Indonesia. 17(6), 1-9.

Kaasa, A. (2018). Intangible factors and productivity: Evidence from Europe at the regional level". Business and Economic Horizons, 14(2), 300-325.

Kaplan and Norton. (1996). The Balanced Scorecard, Translating Strategy into Action. Harvard Business School.

Keller, K., \& Lane, K. (2013). Marketing Management. New Jersey: Prentice Hall.

Kumar, P. J., \& Kumar, P. A. A. (2017). Employee Empowerment - An Empirical Study. 17(4).

Molefi, A. (2009). Some beneficiaries abuse programme. DailyNews, 128, 19. 
Ongori \& Migiro. (2011). Enhancing SMEs competitiveness: The strategies to resolve Barriers to information communication technologies adopted by SMEs. A paper presented in 2011 International Conference on Innovation and Growth. University of Botwsana.

Panjung Rusnadi, et al. (2009). Survey of South Sulawesi local industry. Hasanuddin University Spatial Planning and Regional Development Division.

Rakib, M., \& Azis, M. (2020). The influence of entrepreneurship training, individual commitment and business motivation toward the small businesses performance in city of parepare. 3, 135-141.

Situmorang \& Situmorang. (2008). SMEs business climate in the Era of Regional Autonomy. INFOKOP, 1.

Esta obra está bajo una Licencia Creative Commons

Attribución-NoCommercial 4.0 International

(cc) EY-NC 